Original article

\title{
Low temperature resistance in saplings and ramets of Polylepis sericea in the Venezuelan Andes
}

\author{
Fermín Rada ${ }^{\mathrm{a}, *}$, Carlos García-Núñez ${ }^{\mathrm{a}}$, Sairo Rangel ${ }^{\mathrm{b}}$ \\ ${ }^{a}$ Instituto de Ciencias Ambientales y Ecológicas (ICAE), Facultad de Ciencias, Universidad de Los Andes, Mérida 5101, Venezuela \\ ${ }^{\mathrm{b}}$ Laboratorio de Microbiología y Fisiopatología, Coordinación de Ingeniería de la Producción Agropecuaria, Universidad Experimental Sur del Lago, \\ Santa Bárbara, Zulia, Venezuela
}

\section{A R T I C L E I N F O}

\section{Article history:}

Received 20 February 2009

Accepted 18 May 2009

Published online $\mathrm{xxx}$

\section{Keywords:}

Tropical high mountains

Treeline

Rock outcropings

Low temperature avoidance

\begin{abstract}
A B S T R A C T
The frequent occurrence of all year-round below zero temperatures in tropical high mountains constitutes a most stressful climatic factor that plants have to confront. Polylepis forests are found well above the continuous forest line and are distributed throughout the Andean range. These trees require particular traits to overcome functional limitations imposed on them at such altitudes. Considering seedling and sapling stages as filter phases in stressful environments, some functional aspects of the regeneration of Polylepis sericea, a species associated to rock outcrops in the Venezuelan Andes, were studied. We characterized microclimatic conditions within a forest, in a forest gap and surrounding open páramo and determined low temperature resistance mechanisms in seedlings, saplings and ramets. Conditions in the forest understory were more stable compared to the forest gaps and open surrounding páramo. Minimum temperatures close to the ground were $3.6^{\circ} \mathrm{C}$ lower in the open páramo compared to the forest understory. Maximum temperatures were $9.0^{\circ} \mathrm{C}$ higher in the open páramo. Ice nucleation and injury temperatures occurred between -6 and $-8{ }^{\circ} \mathrm{C}$ for both ramets and saplings, an evidence of frost avoidance to low nighttime temperatures. In this particular forest, this resistance ability is determinant in their island-like distribution in very specific less severe temperature habitats.
\end{abstract}

(ㄷ) 2009 Elsevier Masson SAS. All rights reserved.

\section{Introduction}

In contrast to temperate regions where plants are subjected to large seasonal temperature oscillations, tropical high mountains present relatively steady mean temperatures throughout the year. But, more importantly, freezing temperatures may occur any night of the year. Therefore, not only the occurrence of below zero temperatures but their frequency, constitute an important stressful climatic factor that plants have to confront in these environments (Rundel, 1994).

Polylepis (Rosaceae) forests are found at the treeline in the South American Andes. The occurrence of this genus well above the reported worldwide elevation limit for trees points to the presence of unique functional responses that permit them to overcome different environmental imposed limitations. Polylepis sericea WEDD., the only species within the genus found in the Venezuelan Andes, is distributed between 3100 and $4500 \mathrm{~m}$ associated to rock outcrops (Arnal, 1983). Azócar and Monasterio (1980) described more favorable temperature conditions in these forest islands

\footnotetext{
* Corresponding author.

E-mail address: frada@ula.ve (F. Rada).
}

compared to the surrounding open páramo. Additionally, very unique responses in terms of daily and seasonal osmotic adjustments to enhance the supercooling capacity of leaves and to maintain water uptake and a positive cabon balance in periods of water deficits have been reported for $P$. sericea adult trees (Rada et al., 1985, 1996).

Considering seedling and sapling stages as filter phases that may determine success in a stressful environment, it is important to focus on the functional aspects that may explain this species' establishment strategies. Different studies have evaluated natural regeneration of Polylepis species (Renison et al., 2002; Enrico et al., 2004; Hoch and Körner, 2005; Cierjacks et al., 2007; Torres et al., 2008). In the particular case of $P$. sericea, Hueck (1960) reported a high seedling regeneration rate under the canopy of adult trees. On the other hand, a 100\% mortality rate was reported for seedlings transplanted to the open páramo compared to an $86 \%$ mortality rate under rock outcrop conditions (Smith, 1977). However, no studies have addressed the issue of low temperature resistance in these early stages. A question arises: is this limitation to go beyond the forest island environment into the surrounding páramo related to low temperature resistance barriers? In order to answer this question we characterized, for one particular forest, low temperature resistance mechanisms in relation to microclimatic conditions 
within the forest and in the surrounding open páramo. On the other hand, Rangel (2004) determined that, for the forest in Páramo de Mucubaji (3700 m asl), P. sericea's regeneration consisted mainly of ramets (56\%), nonetheless seed germination (44\%) was also important. Are there significant differences in low temperature resistance between these two regeneration strategies which may explain the greater survival of ramets over seedlings?

\section{Materials and methods}

\subsection{Study area and microclimatic characterization of the forest}

The studied $P$. sericea forest was located at an altitude of $3700 \mathrm{~m}$ in the Páramo de Mucubají, Sierra de Santo Domingo in Mérida, Venezuela ( $8^{\circ} 47^{\prime} \mathrm{N}, 70^{\circ} 48^{\prime} \mathrm{W}$ ). It corresponds to a relatively open canopy forest located within rock outcrops in an eastern facing slope with neighboring rosette-shrub and rosette-grass vegetation associations of the open páramo (Fig. 1). Mean annual temperature for Páramo de Mucubají is $5.4{ }^{\circ} \mathrm{C}$ with a $1.2{ }^{\circ} \mathrm{C}$ difference between the coldest (December) and warmest (June) month. Mean annual precipitation is $969 \mathrm{~mm}$, presenting an unimodal distribution with a distinct dry season between December and February.

Daily temperatures were registered at 5 min intervals for 109 days between October and February, including both wet and dry seasons. Two two-channel data loggers (HOBO, USA) with sensors placed at $5 \mathrm{~cm}$ above and $7 \mathrm{~cm}$ below the ground surface in both forest understories and open páramo were used. Two one-channel temperature loggers (HOBO, USA) were placed at $50 \mathrm{~cm}$ above the soil surface at each site. Additionally, a two-channel temperature logger with sensors at $5 \mathrm{~cm}$ above and $7 \mathrm{~cm}$ below the ground was also placed in the middle of a wide forest gap to determine if saplings or ramets may be restricted from these areas due to temperature conditions. One-way ANOVA and Tukey's HSD tests were used in order to determine degree of significance in temperatures between sites.

\subsection{Low temperature resistance}

\subsubsection{Determination of ice nucleation temperature}

Saplings and ramets $(<10 \mathrm{~cm}$ height), and seedlings were transplanted in the field into plastic bags, brought to the laboratory

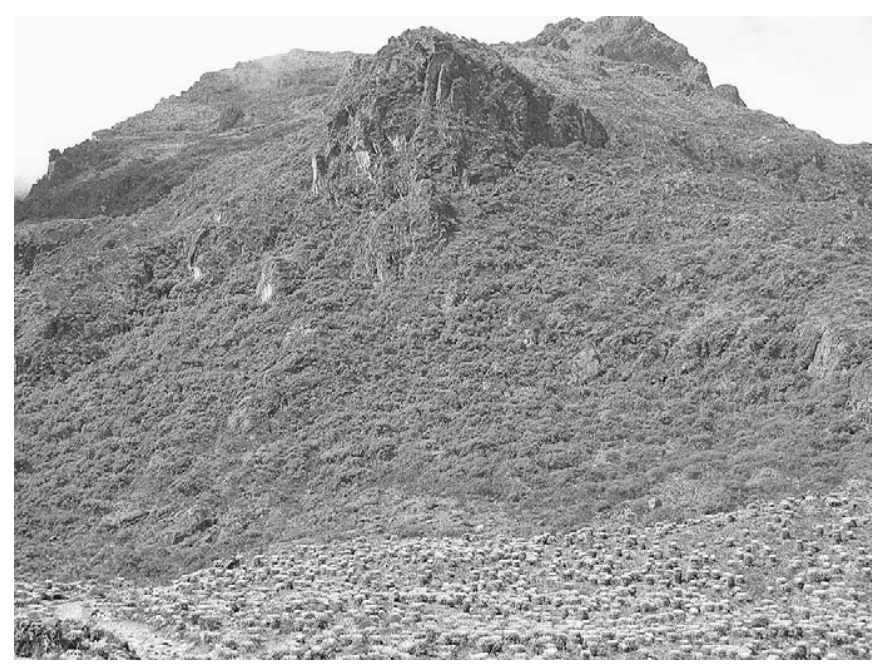

Fig. 1. Transition zone between the open páramo and the $P$. sericea forest. Giant rosette (Espeletia schultzii)-grass association in the lower left corresponding to the open páramo, and $P$. sericea trees from the middle to the upper right of the picture associated to rock outcroppings (photo: Y. Cáceres). and kept in a growth chamber at $5{ }^{\circ} \mathrm{C}$ overnight until the next morning when experiments were carried out. Whole leaves and stem sections for saplings and ramets $(n=15)$ and entire seedlings $(n=8)$ were placed in test tubes with copper-constantan thermocouples inserted in the samples and hermetically sealed. Temperature was recorded continuously through an interphase (Model PA-7018 ICP.CON) attached to a computer. The test tubes were immersed in an alcohol low temperature bath (Grant Instruments Co.) and temperature was monitored from $+5{ }^{\circ} \mathrm{C}$ to $-30{ }^{\circ} \mathrm{C}$ at a cooling rate of $8.7^{\circ} \mathrm{C} \mathrm{h}^{-1}$. The ice nucleation temperature corresponded to the point at which an increase in temperature due to heat release during the freezing process (appearance of an exotherm) was detected by the thermocouples.

\subsection{Determination of injury temperature}

Injury temperatures for whole leaves and stem sections were determined through the refined Triphenyl Tetrazolium Chloride (TTC) method described by Steponkus and Lanphear (1967). Samples taken from plants brought to the laboratory (as described in the previous section) were placed in sealed test tubes and inserted in the refrigerated alcohol bath. Temperature was lowered from $+5{ }^{\circ} \mathrm{C}$ down to $-30{ }^{\circ} \mathrm{C}$ at $8.7{ }^{\circ} \mathrm{C} \mathrm{h}^{-1}$. At $5{ }^{\circ} \mathrm{C}$ intervals, temperature was stabilized for 5 min and samples of each section $(n=3)$ were removed from the bath. These samples, including the reference temperature $\left(5^{\circ} \mathrm{C}\right)$, were incubated at $5^{\circ} \mathrm{C}$ for $8 \mathrm{~h}$. After this incubation period, $5 \mathrm{ml}$ of TTC were added and left at $5{ }^{\circ} \mathrm{C}$ for $24 \mathrm{~h}$. Afterwards, the formazan produced by the reduction of the TTC was extracted from the samples with $95 \%$ ethanol in a boiling water bath for $10 \mathrm{~min}$. Absorbance at $530 \mathrm{~nm}$ was then determined for each sample. Injury temperature corresponded to a $50 \%$ absorbance reduction of the samples in relation to the absorbance of the sample at the reference temperature $\left(5^{\circ} \mathrm{C}\right)$.

Mann-Whitney $U$ tests were used to determine significance between supercooling capacity and injury temperature for both saplings and ramets and to determine if there were significant differences in supercooling capacity and injury temperature between saplings and ramets.

\section{Results}

\subsection{Microclimatic characterization of the forest}

P. sericea forest understories offer a less oscillating thermal environment compared to forest gaps and open surrounding páramo (Table 1). With respect to low nighttime temperatures, both the forest gap and the open páramo responded similarly. In terms of mean below zero temperature duration at $5 \mathrm{~cm}$ above the ground, the understories had an average of $57 \pm 16$ and $471 \pm 36 \mathrm{~min} / \mathrm{night}$ during wet and dry seasons, respectively. While the forest gap (235 \pm 37 and $599 \pm 37 \mathrm{~min} /$ night $)$ and the open páramo (238 \pm 40 and $600 \pm 39 \mathrm{~min} /$ night) had significantly higher averages during both wet and dry seasons. Temperature decreased rapidly after sundown reaching absolute minimum temperatures between 6:00 and 7:00 during both seasons and increased abruptly above $0{ }^{\circ} \mathrm{C}$ after sunrise at all sites. Clear distinctions were observed between wet and dry seasons, mainly in minimum daily low temperatures. Significant differences in minimum temperatures were found between the forest understory and the open páramo, with differences of 3.6 and $4.6{ }^{\circ} \mathrm{C}$ for mean and absolute minimum temperatures, respectively, during the colder dry season (Table 1). It is important to note that the open páramo and the forest gap also showed a greater number of days with temperatures below zero (94\%) when compared to the adjacent forest understory (69\%). Wet-dry combined mean ground level temperature did not 
Table 1

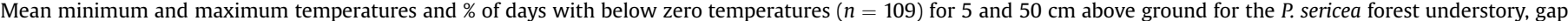

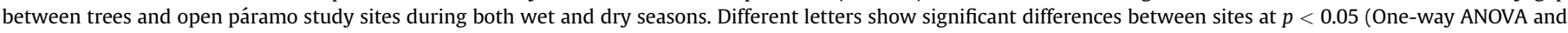
Tukey's HSD). Absolute minimum and maximum measured in parenthesis.

\begin{tabular}{|c|c|c|c|c|c|c|}
\hline Season & $5 \mathrm{~cm}>$ ground & & $50 \mathrm{~cm}>$ ground & & $5 \mathrm{~cm}>$ ground & $50 \mathrm{~cm}>$ ground \\
\hline WET & $\operatorname{Min}\left({ }^{\circ} \mathrm{C}\right)$ & $\operatorname{Max}\left({ }^{\circ} \mathrm{C}\right)$ & $\operatorname{Min}\left({ }^{\circ} \mathrm{C}\right)$ & $\operatorname{Max}\left({ }^{\circ} \mathrm{C}\right)$ & $\%$ days $<0{ }^{\circ} \mathrm{C}$ & $\%$ days $<0{ }^{\circ} \mathrm{C}$ \\
\hline Forest understory & $2.4 \pm 0.2^{\mathrm{a}}(-0.3)$ & $12.2 \pm 0.3^{\mathrm{a}}(17.8)$ & $1.9 \pm 0.1^{\mathrm{a}}(-2.0)$ & $12.2 \pm 0.2^{\mathrm{a}}(17.9)$ & 8.1 & 1.7 \\
\hline Forest gap & $0.1 \pm 0.2^{\mathrm{b}}(-3.2)$ & $18.4 \pm 0.4^{\mathrm{b}}(27.3)$ & - & - & 56.1 & - \\
\hline Páramo & $0.1 \pm 0.2^{\mathrm{b}}(-3.3)$ & $20.9 \pm 0.6^{\mathrm{c}}(27.6)$ & $0.6 \pm 0.1^{\mathrm{b}}(-3.9)$ & $16.3 \pm 0.3^{b}(20.2)$ & 58.6 & 37.1 \\
\hline \multicolumn{7}{|l|}{ DRY } \\
\hline Forest understory & $-0.8 \pm 0.3^{\mathrm{a}}(-4.9)$ & $14.0 \pm 0.4^{\mathrm{a}}(17.5)$ & $-0.6 \pm 0.3^{\mathrm{a}}(-4.3)$ & $14.0 \pm 0.4^{\mathrm{a}}(19.9)$ & 69.3 & 65.4 \\
\hline Forest gap & $-4.1 \pm 0.5^{\mathrm{b}}(-9.9)$ & $21.1 \pm 0.7^{b}(28.3)$ & - & - & 94.2 & - \\
\hline Páramo & $-4.4 \pm 0.4^{\mathrm{b}}(-9.5)$ & $23.0 \pm 0.6^{c}(28.6)$ & $-2.0 \pm 0.1^{\mathrm{b}}(-5.3)$ & $18.3 \pm 0.1^{\mathrm{b}}(21.7)$ & 94.3 & 84.6 \\
\hline
\end{tabular}

significantly vary between the forest understory, the forest gap and open páramo, $5.95 \pm 0.10{ }^{\circ} \mathrm{C}, 5.80 \pm 0.17{ }^{\circ} \mathrm{C}$ and $6.19 \pm 0.17{ }^{\circ} \mathrm{C}$, respectively $(F(1,216)=1.60, P=0.21)$. Moreover, there were no significant mean temperature differences $(F(2,324)=1.72, P=0.18)$ between forest understory, gap and páramo below the soil surface (wet-dry seasons mean minimum of $5.68 \pm 0.13{ }^{\circ} \mathrm{C}, 5.86 \pm 0.16{ }^{\circ} \mathrm{C}$ and $6.08 \pm 0.20^{\circ} \mathrm{C}$, respectively).

\subsection{Low temperature resistance}

Injury temperature was not determined in seedlings to avoid the extraction of a large number of plants needed to carry out the corresponding methodology. However, determinations of the initiation of ice formation gave similar results to those of other tissues, leaves and stems, of juveniles in this study (Table 2). No significant differences were observed between ice nucleation temperature and injury temperature for either saplings or ramets, indicating that the ice nucleation process resulted in tissue damage. Additionally, there were no significant differences in either of these variables when saplings and ramets were compared.

\section{Discussion}

\subsection{Microclimatic conditions in the Polylepis forest and the surrounding páramo}

Conditions within the forest understory were less extreme compared to the gap and/or open páramo, with differences of up to $5{ }^{\circ} \mathrm{C}$ in recorded minimum temperatures just above the soil surface. This supports Azócar and Monasterio (1980) who indicated that night temperatures are lower in the open páramo in relation to the forest, while during the day, the forest may be cooler than the páramo. A lower number of nights with frosts also occur inside the forest compared to the open páramo (Azócar and Monasterio, 1980; Lauer, 1981). In general, thermal oscillations are far more pronounced in the open páramo, mainly during the dry season, compared to the Polylepis forest. Smith (1977), in 24 h courses, found

\section{Table 2}

Supercooling capacity and injury temperature for seedlings, and leaves and stems of saplings and ramets. There were no significant differences $(p<0.05$, U MannWhitney) between supercooling capacity and injury temperature in saplings or ramets pointing to frost avoidance mechanisms. There were no significant differences ( $p<0.05, U$ Mann-Whitney) between leaves or stems of saplings and ramets in supercooling capacity or injury temperature.

\begin{tabular}{lll}
\hline & Supercooling capacity $\left({ }^{\circ} \mathrm{C}\right)$ & Injury temperature $\left({ }^{\circ} \mathrm{C}\right)$ \\
\hline Seedlings & $-6.6 \pm 1.6$ & - \\
Sapling leaves & $-6.2 \pm 1.1$ & $-5.6 \pm 1.3$ \\
Sapling stems & $-5.4 \pm 0.4$ & $-6.5 \pm 1.0$ \\
Ramet leaves & $-6.0 \pm 0.9$ & $-7.0 \pm 1.3$ \\
Ramet stems & $-6.2 \pm 0.6$ & $-7.8 \pm 1.8$ \\
\hline
\end{tabular}

minimum and maximum temperatures of -6 and $36^{\circ} \mathrm{C}$ in the open páramo of Mucubají, while within the rock outcrops, where Polylepis is found, minimum and maximum were -3 and $33^{\circ} \mathrm{C}$, respectively. Bader et al. (2007a) describe larger temperature fluctuations in open vegetation compared to the adjacent forests in six tropical and subtropical treeline sites along the Andes. All this corroborates that the forest in this study, associated to rock outcrops, creates a more stable microclimate, which dampens the extreme conditions of the existing periglacial climate more efficiently.

Cavieres et al. (2000) suggest that temperature extremes have a more direct effect on plant response, therefore explaining treeline distribution patterns better than daily or seasonal mean temperatures. Our results show no significant differences in mean seasonal ground level or belowground temperatures between understory, gap and open páramo. Root-zone temperatures measured in this study coincide with those reported for other tropical treelines (Körner and Paulsen, 2004). Kessler and Hohnwald (1998) found that root-zone average temperatures at three sites, forested and treeless boulder areas and in adjacent unforested areas at $4050 \mathrm{~m}$ asl in Bolivia, were only $2{ }^{\circ} \mathrm{C}$ lower within the forested and $1{ }^{\circ} \mathrm{C}$ lower in the treeless boulder areas compared to the unforested areas. Our results suggest that belowground temperature does not explain the limitations to tree establishment in these treeline environments. However, higher surface nighttime temperatures together with a reduced occurrence of frost events must have an important influence on sapling survival in this rock outcrop-forest canopy association.

\subsection{Low temperature resistance mechanisms}

The higher survival rate in ramets compared to saplings (Rangel, 2004) may not be explained by low temperature resistance mechanisms. Other factors, discussed ahead, related to water and/or light environments may explain this difference. Both saplings and ramets show strict avoidance mechanisms for survival under subzero temperatures. The similarity of ice nucleation and injury temperatures, suggests that the latter one is a consequence of ice crystal formation. According to Larcher (1995), juvenile plants are more sensitive to freezing conditions compared to adults. P. sericea adult trees also avoid freezing (Azócar et al., 2007) although injury temperatures $\left(-8\right.$ to $-9^{\circ} \mathrm{C}$ ) are slightly lower compared to our results in this study. These results support Larcher's statement on the sensitivity of juveniles in relation to adult plants. In general, the results for $P$. sericea adult trees (Azócar et al., 2007) and saplings or ramets (this study) in a more tropical environment contrast with those of Polylepis tarapacana (Rada et al., 2001) and Polylepis australis (Azócar et al., 2007), two species growing at higher latitudes which tolerate ice formation in their tissues. It is interesting to point out that P. sericea has the widest latitudinal distribution of all Polylepis species (Simpson, 1979) ranging from Venezuela down to Western Bolivia. In its most southern latitude, $P$. sericea is restricted to the most humid and warmer sites of any of the Polylepis species (Kessler, 2002). 
The attenuation of minimum night temperatures described previously for $P$. sericea forest islands is a determinant factor in their success in these "thermal refugees" and may also explain their limited capacity to colonize open páramo habitats. Nevertheless, other factors may be involved such as inhibitory high radiation inputs (Enrico et al., 2004; Cierjacks et al., 2007) or unfavourable water conditions (Heinemann et al., 2000) of more open habitats. Bader et al. (2007b) find that excess solar radiation restricts tree regeneration above the tropical treeline in a study of different tree species of northern Ecuador. However, it is clear that for our particular open páramo site, frequent minimum temperatures $\left(-9.5{ }^{\circ} \mathrm{C}\right.$ in this study) are below leaf or stem injury temperatures described for $P$. sericea saplings or ramets. Consequently, $P$. sericea, in its early stages, is not capable of colonizing open páramo areas and is restricted to the forest understory.

In conclusion, even though further studies are needed to understand the establishment and development of Polylepis juveniles under the extreme conditions of tropical and subtropical high mountain environments, it is clear that in the particular case of $P$. sericea in Venezuela, low temperature resistance mechanisms are determinant in their island-like distribution in very specific less severe temperature habitats. Other authors have suggested fire as the determinant factor in the establishment of Polylepis in Argentina (Renison et al., 2002) and Ecuador (Coblentz and Keating, 2008). However, fire has not been described as a factor which may influence $P$. sericea's distributional patterns in the Venezuelan Andes. As Bader et al. (2007b) state, the existence of natural processes that can explain the abruptness of tropical treelines points to the need of being critical of fire-dominated views many authors have accepted. Our results suggest that the establishment of young plants in these particular habitats comes down to a temperature buffering effect provided by the rock outcroppingforest canopy arrangement. Other factors, such as water and light availability which are also modified by rock outcrops and forest canopies, may also have an impact on natural regeneration of $P$. sericea. It would be interesting to carry out research on $P$. sericea forests in their low altitude limit, in the case of Venezuela it is reported at $3100 \mathrm{~m}$, where nighttime temperature conditions would not play a determinant role. If these forests are still associated to rock outcroppings it would point out to other factors different from freezing nighttime temperatures. Finally, our results support those of other authors which indicate that the critical phase for Polylepis tree establishment corresponds to the seedling to sapling transition (Enrico et al., 2004; Hoch and Körner, 2005).

\section{Acknowledgements}

Financial aid provided by the IAI (Grant \# CRN-040). We are grateful to P. Alvizú and E. Márquez for their support in data analysis and laboratory determinations and A. Nieto for fieldwork assistance. F Rada wishes to thank the Rockefeller Center for Latin American Studies and the Harvard Forest for their support during his stay at Holbrook's Lab.

\section{References}

Arnal, H., 1983. Estudio Ecológico del Bosque alti-andino de Polylepis sericea WEBB en la Cordillera de Mérida. Unpublished Undergraduate Thesis. Universidad Central de Venezuela, Caracas, Venezuela.
Azócar, A., Monasterio, M., 1980. Estudio de la Variabilidad Meso y Microclimatica en el Páramo de Mucubají. In: Monasterio, M. (Ed.), Estudios Ecológicos en los Páramos Andinos. Ediciones de la Universidad de los Andes, Mérida, Venezuela, pp. 225-262.

Azócar, A., Rada, F., García-Núñez, C., 2007. Functional characteristics of the arborescent genus Polylepis along a latitudinal gradient in the high Andes. Interciencia 32, 663-668.

Bader, M.Y., Rietkerk, M., Bregt, A.K., 2007a. Vegetation structure and temperature regimes of tropical alpine treelines. Arctic. Antarctic and Alpine Research 39, 353-364.

Bader, M.Y., van Geloof, I., Rietkerk, M., 2007b. High solar radiation hinders tree regeneration above the alpine treeline in northern Ecuador. Plant Ecology 191, 33-45.

Cavieres, L., Rada, F., Azócar, A., García-Núñez, C., Cabrera, H.M., 2000. Gas exchange and low temperature resistance in two tropical high mountain tree species from the Venezuelan Andes. Acta Oecologica 21, 203-211.

Cierjacks, A., Wesche, K., Hensen, I., 2007. Potential lateral expansion of Polylepis forest fragments in central Ecuador. Forest Ecology and Management 242, 477-486.

Coblentz, D., Keating, P.L., 2008. Topographic controls on the distribution of tree islands in the high Andes of south-western Ecuador. Journal of Biogeography 35, 2026-2038.

Enrico, L., Funes, G., Cabido, M., 2004. Regeneration of Polylepis australis Bitt. in the mountains of central Argentina. Forest Ecology and Management 190, 301-309.

Heinemann, K., Kitzberger, T., Veblen, T.T., 2000. Influences of gap microheterogeneity on the regeneration of Nothofagus pumilio in a xeric old-growth forest of northwestern Patagonia, Argentina. Canadian Journal of Forest Research 30, 25-31.

Hoch, G., Körner, Ch., 2005. Growth, demography and carbon relations of Polylepis trees at the world's highest treeline. Functional Ecology 19, 941-951.

Hueck, K., 1960. Los Bosques de Polylepis sericea en los Andes Venezolanos. Boletín IFLA 6, 1-33.

Kessler, M., 2002. The "Polylepis problem": where do we stand? Ecotropica 8 97-110.

Kessler, M., Hohnwald, S., 1998. Bodentemperaturen innerhalb und ausserhalb bewaldeter und unbewaldeter blockhalden in den Bolivianischen hochanden. Ein test der hypothese von Walter und Medina (1969). Erdkunde 52, 54-62.

Körner, Ch., Paulsen, J., 2004. A world-wide study of high altitude treeline temperatures. Journal of Biogeography 31, 713-732.

Larcher, W., 1995. Physiological Plant Ecology. Springer-Verlag, Berlin.

Lauer, W., 1981. Ecoclimatological conditionsor the páramo belt in the tropical high mountains. Mountain Research and Development 1, 209-221.

Rada, F., Azócar, A., Briceño, B., González, J., García-Núñez, C., 1996. Carbon and water balance in Polylepis sericea, a tropical treeline species. Trees 10, 218-222.

Rada, F., García-Nuñez, C., Boero, C., Gallardo, M., Hilal, M., González, J., Prado, F Liberman-Cruz, M., Azócar, A., 2001. Low-temperature resistance in Polylepis tarapacana, a tree growing at the highest altitudes in the world. Plant, Cell and Environment 24,1-5.

Rada, F., Goldstein, G., Azócar, A., Meinzer, F.C., 1985. Daily and Seasonal osmotic changes in a tropical treeline species. Journal of Experimental Botany 36, 989-1000.

Rangel, S., 2004. Ecofisiología de la regeneración de Polylepis sericea WEDD.: Tipo de reproducción y mecanismos de resistencia a las temperaturas congelantes. Unpublished Undergraduate Thesis. Bodentemperaturen innerhalb und ausserhalb bewaldeter und unbewaldeter blockhalden in den Bolivianischen hochanden. Ein test der hypothese von Walter und Medinaub, Mérida, Venezuela.

Renison, D., Cingolani, A.M., Suárez, R., 2002. Efectos del fuego sobre un bosquecillo de Polylepis australis (Rosaceae) en las montañas de Córdoba, Argentina. Revista Chilena de Historia Natural 75, 719-727.

Rundel, P., 1994. Tropical alpine climates. In: Rundel, P.W., Smith, A.P., Meinzer, F.C. (Eds.), Tropical Alpine Environments: Plant Form and Function. Cambridge University Press, pp. 21-44.

Simpson, B., 1979. A Revision of the Genus Polylepis (Rosaceae: Sanguisorbeae) Smithsonian Contributions to Botany, vol. 43. Smithsonian Institution Press, Washington.

Smith, A.P., 1977. Establishment of seedlings of Polylepis sericea in the páramo (Alpine) zone of the Venezuelan Andes. Bartonia 45, 11-14.

Steponkus, P.L., Lanphear, F.O., 1967. Refinement of the Triphenyl Tetrazolium Chloride method of determining cold injury. Plant Physiology 42 1423-1426.

Torres, R.C., Renison, D., Hensen, I., Suárez, R., Enrico, L., 2008. Polylepis australis' regeneration niche in relation to seed dispersal, site characteristics and livestock density. Forest Ecology and Management 254, 255-260. 